\title{
Characterization of parathyroid hormone/parathyroid hormone-related protein receptor and signaling in hypercalcemic Walker 256 tumor cells
}

\author{
P Esbrit, J Benítez-Verguizas, F de Miguel, A Valín and \\ A García-Ocaña \\ Bone and Mineral Metabolism Laboratory, Research Unit, Fundación Jiménez Díaz, Madrid, Spain \\ (Requests for offprints should be addressed to P Esbrit, Bone and Mineral Metabolism Laboratory, Research Unit, Fundación Jiménez Díaz, \\ Avda. Reyes Católicos, 2, 28040 Madrid, Spain) \\ (F de Miguel and A García-Ocaña are now at Division of Endocrinology, Department of Medicine, University of Pittsburgh Medical Center, Pittsburgh, \\ Pennsylvania, USA)
}

\begin{abstract}
Parathyroid hormone (PTH)-related protein (PTHrP) is the main factor responsible for humoral hypercalcemia of malignancy. Both PTH and PTHrP bind to the common type I PTH/PTHrP receptor (PTHR), thereby activating phospholipase $\mathrm{C}$ and adenylate cyclase through various $\mathrm{G}$ proteins, in bone and renal cells. However, various normal and transformed cell types, including hypercalcemic Walker 256 (W256) tumor cells, do not produce cAMP after PTHrP stimulation. We characterized the PTHrP receptor and the signaling mechanism upon its activation in the latter cells. Scatchard analysis of PTHrP-binding data in W256 tumor cells revealed the presence of high affinity binding sites with an apparent $K_{\mathrm{d}}$ of $17 \mathrm{nM}$, and a density of 90000 sites/cell. In addition, W256 tumor cells immunostained with an anti-PTHR antibody, recognizing its extracellular domain. Furthermore, reverse transcription followed by PCR, using primers amplifying two different regions in the PTHR cDNA corresponding to
\end{abstract}

the $\mathrm{N}$ - and C-terminal domains, yielded products from W256 tumor cell RNA which were identical to the corresponding products obtained from rat kidney RNA. Consistent with our previous findings on cAMP production, $1 \mu \mathrm{M}$ PTHrP(1-34), in contrast to $10 \mu \mathrm{g} / \mathrm{ml}$ cholera toxin or $1 \mu \mathrm{M}$ isoproterenol, failed to affect protein kinase A activity in W256 tumor cells. However, in these cells we found a functional PTHR coupling to $G_{\alpha q / 11}$, whose presence was demonstrated in these tumor cell membranes by Western blot analysis. Our findings indicate that W256 tumor cells express the PTHR, which seems to be coupled to $G_{\alpha q / 11}$. Taken together with previous data, these results support the hypothesis that a switch from the cAMP pathway to the phospholipase C-intracellular calcium pathway, associated with PTHR activation, occurs in malignant cells.

Journal of Endocrinology (2000) 166, 11-20

\section{Introduction}

Parathyroid hormone-related protein (PTHrP), initially isolated from hypercalcemia-associated tumors, is produced by a variety of nonmalignant tissues, where it appears to act as an auto/paracrine factor (Philbrick et al. 1996). The N-terminal region of PTHrP exhibits structural homology with that of parathyroid hormone (PTH), which accounts for its binding to the common type I $\mathrm{PTH} / \mathrm{PTHrP}$ receptor (PTHR), cloned in bone and kidney cells, with high affinity (Schipani et al. 1993). In these cells, the PTHR signals via the phospholipase C and adenylate cyclase pathways through interaction with various G proteins (Abou-Samra et al. 1992, Takasu et al. 1999). However, in HTLV-I-infected lymphocytes, in normal rat islet as well as rat insulinoma cells, and in squamous carcinoma cells, incompletely characterized PTHrP receptors show features different from those of PTHR, e.g. low affinity PTHrP binding and/or failure to activate the adenylate cyclase pathway (McCauley et al. 1992, Orloff et al. 1992, 1994, Gaich et al. 1993, Villanueva-Peñacarrillo et al. 1999). In addition, in the latter cells, various mRNA transcripts hybridizing with a human PTHR cDNA have been detected (Orloff et al. 1995). The relationship between these transcripts and the presence of putative PTHrP receptors different from the PTHR in squamous cells is unknown at present.

We previously found that the $\mathrm{N}$-terminal region of PTHrP stimulates cell proliferation and calcium transients, but not cAMP synthesis, in the hypercalcemic cell line WS of the Walker 256 (W256) tumor (Benítez-Verguizas \& Esbrit 1994), which originates in the rat mammary 
gland but has hematopoietic cell features (Simpkins et al. 1991). The present study was carried out to characterize further the PTHrP receptor and signaling in these cells.

\section{Materials and Methods}

\section{Reagents}

Human PTHrP(1-34) amide $(\mathrm{PTHrP}(1-34))$ was from Peninsula Laboratories (Belmont, CA, USA). Human $\left[\mathrm{Tyr}^{36}\right] \mathrm{PTHrP}(1-36)$ amide $(\mathrm{PTHrP}(1-36))$ was a generous gift of Dr A F Stewart (University of Pittsburgh, PA, USA). Recombinant human epidermal growth factor (EGF) was kindly supplied by Serono (Madrid, Spain). Cholera toxin, 3-isobutyl-1-methylxanthine (IBMX), Arg-vasopressin, and isoproterenol were from Sigma ( $\mathrm{St}$ Louis, MO, USA). Kemptide (Leu-Arg-Arg-Ala-SerLeu-Gly) was from Boehringer Mannheim (Mannheim, Germany). $\left[\gamma-{ }^{32} \mathrm{P}\right]$ GTP $(6000 \mathrm{Ci} / \mathrm{mmol})$ was obtained from New England Nuclear (Brussels, Belgium). $\mathrm{Na}^{125} \mathrm{I}$ $(2000 \mathrm{Ci} / \mathrm{mmol})$ was from Amersham International (Amersham, Bucks, UK).

\section{Cell culture}

Walker 256 tumor cells were grown in Dulbecco's modified Eagle's medium (DMEM) containing $50 \mathrm{U} / \mathrm{ml}$ penicillin, $50 \mu \mathrm{g} / \mathrm{ml}$ streptomycin and $10 \%$ fetal bovine serum (FBS) (culture medium), and subcultured weekly by dilution to $5 \times 10^{4}$ cells $/ \mathrm{ml}$ (Benítez-Verguizas \& Esbrit 1994). Cells in the exponential growth stage were used for the following experiments. Human osteoblastic (hOB) cells, supplied by Dr M E Martínez (Department of Biochemistry, Hospital La Paz, Madrid, Spain) were cultured in DMEM with 15\% FBS and antibiotics, as reported previously (Martínez et al. 1997).

\section{PTHrP binding assay}

PTHrP(1-34) was radioiodinated by the Hunter and Greenwood method, with minor modifications (Hunter \& Greenwood 1962). Briefly, $4 \mu \mathrm{g}$ PTHrP were added to $1 \mathrm{mCi} \mathrm{Na}{ }^{125} \mathrm{I}$ in $80 \mu \mathrm{l} 0 \cdot 5 \mathrm{M}$ sodium phosphate, $\mathrm{pH} 7 \cdot 5$. Iodination was allowed to proceed for $3 \mathrm{~min}$ following the addition of $10 \mu \mathrm{l} 1.8 \mathrm{mM}$ chloramine $\mathrm{T}$. The reaction was stopped by adding $50 \mu \mathrm{l} 0 \cdot 1 \mathrm{M}$ sodium metabisulfite. The iodinated hormone was separated from free iodine by using SepPak C18 cartridges (Waters, Milford, MA, USA), and was subsequently purified to maximal specific activity by HPLC on a $\mu$ Bondapak C-18 column with a $60-$ min linear gradient of $27-40 \%$ acetonitrile with $0 \cdot 1 \%$ trifluoroacetic acid, at a flow rate of $1 \mathrm{ml} / \mathrm{min}$ (Orloff et al. 1989).

For binding studies, W256 tumor cell medium was removed, and the cells were preincubated with DMEM containing $0 \cdot 2 \%$ bovine serum albumin (BSA) for $1 \mathrm{~h}$ at $37^{\circ} \mathrm{C}$. Then, the cells were washed and resuspended at a final density of $2 \times 10^{6}$ cells $/ \mathrm{ml}$ in DMEM with $0 \cdot 2 \% \mathrm{BSA}$, and $1 \mu \mathrm{g} / \mathrm{ml}$ pepstatin, $50 \mu \mathrm{g} / \mathrm{ml}$ bacitracin, $60 \mathrm{KIU} / \mathrm{ml}$ aprotinin, $0 \cdot 1 \mathrm{mM}$ phenylmethylsulfonyl fluoride, $1 \mathrm{mM}$ EDTA (protease inhibitor cocktail), 25$30 \times 10^{3}$ c.p.m. labeled PTHrP(1-34) and various concentrations of unlabeled peptide, in a final volume of $100 \mu \mathrm{l}$. Binding was carried out with gentle agitation at $20^{\circ} \mathrm{C}$ for $3 \mathrm{~h}$, when steady-state binding was achieved. Incubations were terminated by the addition of $1 \mathrm{ml}$ cold phosphate-buffered saline (PBS) with $0 \cdot 1 \%$ BSA, and centrifuging at $12000 \mathrm{~g}$ for $5 \mathrm{~min}$. The cell pellet was subsequently washed three times with the same buffer. Cell-bound radioactivity was recovered by the addition of $200 \mu 11 \mathrm{M} \mathrm{NaOH}$, and was $\gamma$-counted.

\section{Immunocytochemistry}

W256 tumor cells were washed with PBS, and deposited on glass slides by cytocentrifugation at $700 \mathrm{~g}$ for $10 \mathrm{~min}$. Human OB cells were plated at $10000 \mathrm{cells} / \mathrm{cm}^{2}$ on multiwell chambers (Labtek; Nunc, Naperville, IL, USA) and cultured until preconfluency. The cells were subsequently fixed in $95 \%$ ethanol, washed with PBS, treated with $3 \% \mathrm{H}_{2} \mathrm{O}_{2}$ for $5 \mathrm{~min}$ to abolish endogenous peroxidase activity, and then incubated with $1.5 \%$ nonimmune goat serum for $10 \mathrm{~min}$. Immunostaining was conducted with $5 \mu \mathrm{g} / \mathrm{ml}$ of the polyclonal anti-rat PTHR antibody VII (Babco, Richmond, CA, USA), recognizing the Nterminal extracellular domain. This antibody detected the PTHR in rat kidney cortex (Largo et al. 1999). Subsequent incubations, $2 \mathrm{~h}$ with the primary antibody, $30 \mathrm{~min}$ with biotinylated anti-rabbit IgG, and $30 \mathrm{~min}$ with avidin-biotin-peroxidase complex (Vectastain Elite; Vector, Burlingame, CA, USA), were performed at room temperature. Positive staining was developed with $3,3^{\prime}-$ diaminobenzidine. As negative controls, some cell preparations were incubated with saline buffer instead of the primary antibody.

\section{$R N A$ isolation and reverse transcription-polymerase chain reaction ( $R T-P C R)$}

Rat kidneys were harvested from adult (300 g) SpragueDawley rats and immediately frozen in liquid nitrogen. Total RNA was prepared from W256 cells and rat kidneys using the Trizol method (Gibco-BRL, Grand Island, NY, USA). Polyadenylated (poly $\mathrm{A}^{+}$) RNA was isolated from W256 cells by oligo(deoxythymidine)-cellulose chromatography (Gibco-BRL).

Complementary DNA was synthesized by reverse transcription of $2-5 \mu \mathrm{g}$ total RNA or $1 \mu \mathrm{g}$ poly $\mathrm{A}^{+}$RNA using the Advantage RT-for-PCR kit (Clontech, Palo Alto, CA, USA) with oligo(dT) $)_{18}$ as primer, in a final volume of $40 \mu \mathrm{l}$. For PCR reactions, $10 \mu \mathrm{l}$ of 2 - to 20 -fold diluted cDNA were added to a reaction mixture $(50 \mu \mathrm{l})$ 
containing $10 \mathrm{mM}$ Tris- $\mathrm{HCl}(\mathrm{pH} 9 \cdot 0), 50 \mathrm{mM} \mathrm{KCl}$, $2.5 \mathrm{mM} \mathrm{MgCl}_{2}, 0.1 \mathrm{mM}$ each deoxynucleotide, $1.25 \mathrm{U}$ Taq DNA polymerase (Promega, Madison, WI, USA), and $0 \cdot 4 \mu \mathrm{M}$ of the specific primers: 5'-GATGCGGA CGATGTCTTTACC-3' (sense), and 5'-GGCGGTCA AATACCTCC-3' (antisense), yielding a 481-bp product, corresponding to nucleotides 151-631 (exons E1-M1) of the rat PTHR cDNA sequence (Abou-Samra et al. 1992), encoding the N-terminal extracellular domain, or $5^{\prime}$ CATTGTGGCAGATCCAGATGC-3' (sense), and 5'AGTCTAGCCCCCTAGTGCC-3' (antisense), yielding a 495-bp product, corresponding to nucleotides 13761870 of this cDNA (exons M6-7/T), encoding a region including the whole C-terminal intracellular tail of the rat PTHR (Abou-Samra et al. 1992). The housekeeping gene, glyceraldehyde 3-phosphate dehydrogenase (GAPDH) was coamplified using specific primers for the rat sequence (García-Ocaña et al. 1998). PCR products were visualized by ethidium bromide staining following electrophoresis on $1.6 \%$ agarose gels. The bands were excised, purified with Quantum Prep Freeze 'N Squeeze Spin columns (Bio-Rad, Hercules, CA, USA) and cloned into the pCRII-TOPO plasmid using the TOPO TA cloning kit as described by the manufacturer (Invitrogen, Carlsbad, CA, USA). Miniprep plasmid DNA was prepared from PCR-product-containing colonies using QIAprep Spin columns (QIAGEN, Valencia, CA, USA). Inserted PCR products were sequenced in both directions using M13 primers and the dideoxy terminators method in an automated ABI PRISM 377 sequencer (Perkin Elmer, Norwalk, CT, USA).

\section{Measurement of cAMP-dependent protein kinase A (PKA)}

W256 tumor cells were maintained in FBS-depleted medium for $24 \mathrm{~h}$. Fifteen minutes before stimulating with the different agonists, this medium was changed to the same fresh FBS-free medium with $10 \mu \mathrm{M}$ IBMX. The cells were then stimulated in this medium with the agonists, $1 \mu \mathrm{M}$ PTHrP(1-34), $1 \mu \mathrm{M}$ isoproterenol for $5 \mathrm{~min}$, or $10 \mu \mathrm{g} / \mathrm{ml}$ cholera toxin, for $2 \mathrm{~h}$. After microcentrifugation for $1 \mathrm{~min}$, followed by two washes with PBS, an ice-cold extraction buffer $(50 \mathrm{mM}$ potassium phosphate, $\mathrm{pH} 7 \cdot 2,10 \mathrm{mM}$ EGTA, $10 \mathrm{mM}$ EDTA, $2 \mathrm{mM}$ IBMX, 2\% Triton X-100, 0.2 mM dithiothreitol, $20 \mathrm{mM} \mathrm{NaF}$ ) was added to the cell pellet. The cells were gently vortexed and then microcentrifuged for $1 \mathrm{~min}$. PKA activity in the resulting supernatant was determined as previously described (Valín et al. 1997). PKA activity was expressed as the ratio of activity measured in the absence of added cAMP to that in the presence of $6.25 \mu \mathrm{M}$ cAMP.

\section{Western blotting of $\mathrm{G}_{a q / 11}$ proteins}

W256 cell membranes were prepared from subconfluent W256 cell cultures. The cells $\left(20 \times 10^{6}\right.$ cells $\left./ \mathrm{ml}\right)$ in PBS with the protease inhibitor cocktail described above, were homogenized by sonication three times for $15 \mathrm{~s}$ in a Branson (Danbury, CT, USA) B-12 sonifier, at maximal setting. The resulting suspension was centrifuged at $100000 \mathrm{~g}$ for $1 \mathrm{~h} \mathrm{at} 4{ }^{\circ} \mathrm{C}$. The pellet containing cell membrane fragments was resuspended in the same buffer and stored at $-70{ }^{\circ} \mathrm{C}$. Membrane proteins $(30 \mu \mathrm{g})$ were electrophoresed on a $12 \%$ sodium dodecyl sulfatepolyacrylamide gel under reducing conditions, according to the method of Laemmli (1970). The separated proteins were transferred to a nitrocellulose membrane filter (Amersham International) by electroblotting, and then it was blocked with PBS containing 0.1\% Tween (PBT), with 5\% blocking agent (Amersham International) and 1\% $\mathrm{BSA}$, for $2 \mathrm{~h}$ at room temperature. After washing twice with PBT, the membrane was incubated for $1.5 \mathrm{~h}$, at room temperature, with $4 \mu \mathrm{g}$ of a rabbit polyclonal anti- $\mathrm{G}_{\alpha \mathrm{q} / 11}$ antiserum (C-19; Santa Cruz Biotechnology, Santa Cruz, CA, USA), which had been pre-incubated with or without $4 \mu \mathrm{g} \mathrm{G}_{\alpha \mathrm{q} / 11}$ protein for $2 \mathrm{~h}$ at $4{ }^{\circ} \mathrm{C}$. After two washes with PBT, the membrane was incubated with horseradish peroxidase-labeled donkey anti-rabbit IgG for $1 \mathrm{~h}$, and then developed with an enhanced chemiluminescence method (ECL; Amersham International).

\section{GTPase assay}

Measurement of GTPase activity was performed as described by Thibonnier et al. (1993), with minor modifications. W256 tumor cell membranes (5 $\mu \mathrm{g}$ protein) were incubated with either different concentrations of the aforementioned specific anti- $\mathrm{G}_{\alpha \mathrm{\alpha q} / 11}$ rabbit antiserum or $500 \mathrm{ng} / \mathrm{ml}$ nonimmunogenic rabbit IgG for $2 \mathrm{~h}$ at $4{ }^{\circ} \mathrm{C}$. W256 cell membranes were then incubated with or without $1 \mathrm{nM} \mathrm{PTHrP}(1-36)$, in $100 \mu$ l containing $50 \mathrm{mM}$ Tris-HCl, $100 \mathrm{mM} \mathrm{NaCl}, 0.1 \mathrm{mM}$ EGTA, $10 \mathrm{mM}$ $\mathrm{MgCl}_{2}, 0 \cdot 2 \mathrm{mM}$ ATP, $5 \mathrm{mM}$ creatine phosphate, $100 \mathrm{U} /$ $\mathrm{ml}$ creatine kinase, $0 \cdot 2 \mathrm{mM}$ ouabain, $0 \cdot 1 \% \mathrm{BSA}, 500000$ c.p.m./tube $\left[\gamma-{ }^{32} \mathrm{P}\right] \mathrm{GTP}$, for $10 \mathrm{~min}$ at $30{ }^{\circ} \mathrm{C}$. The reaction was terminated with $750 \mu \mathrm{l}$ cold $5 \%$ activated charcoal in $50 \mathrm{mM}$ potassium phosphate, $\mathrm{pH} 7 \cdot 5$. After centrifugation at $1200 \mathrm{~g}$ for $30 \mathrm{~min}$ at $4{ }^{\circ} \mathrm{C}$, the supernatant was counted in a liquid scintillation counter. GTPase activity was calculated after subtracting the c.p.m. obtained in this assay in the absence of cell membranes (nonspecific activity), and expressed as fmol $\times \min ^{-1} \times \mathrm{mg}$ protein $^{-1}$.

\section{Statistics}

Results are expressed as means \pm S.D. throughout the text. Statistical significance $(P<0 \cdot 05$ or lower) was evaluated by either unpaired $t$-test or one-way analysis of variance, when appropriate. 


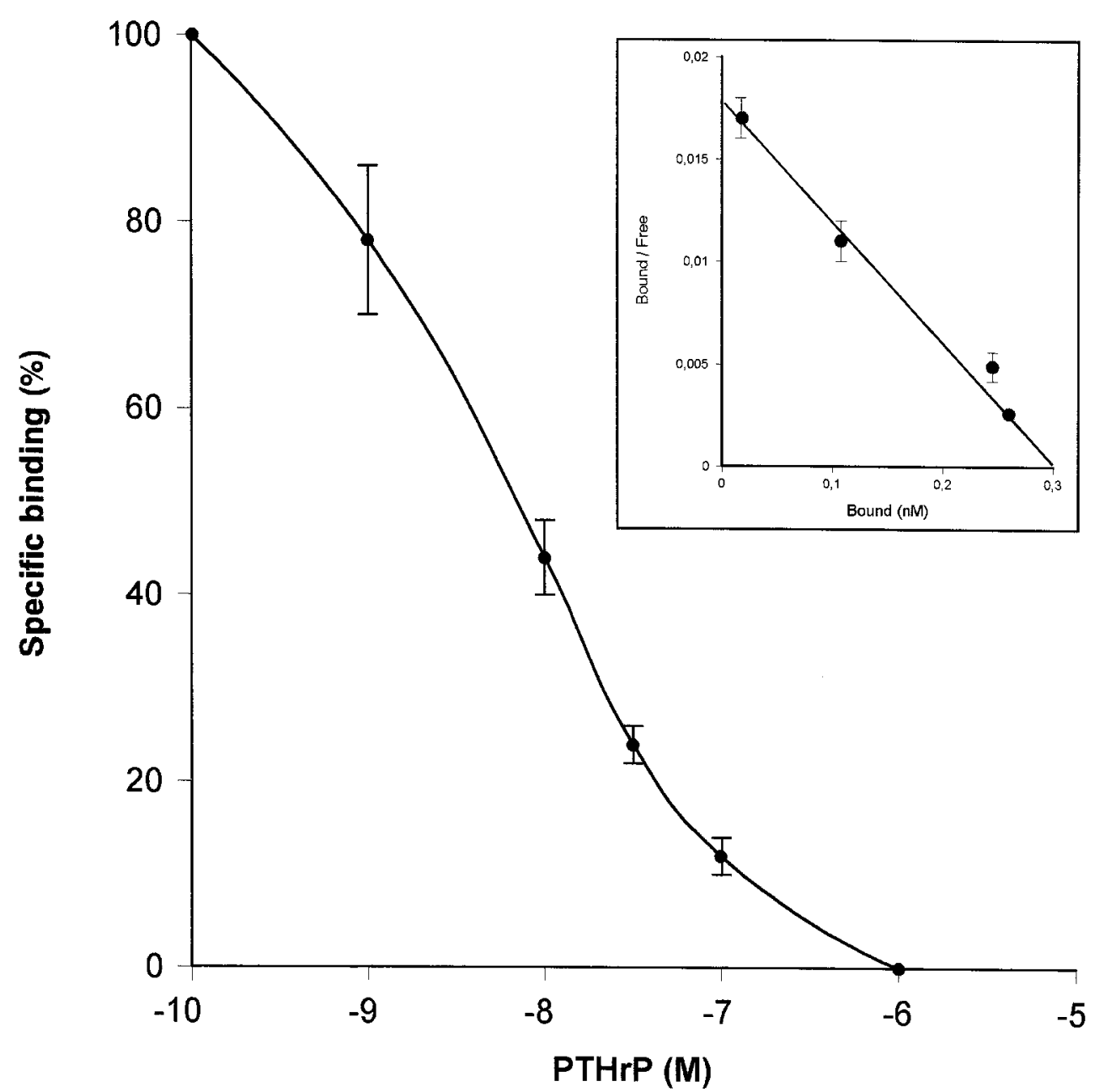

Figure 1 Competition binding of ${ }^{125} \mathrm{I}-\mathrm{PTHrP}(1-34)$ to W256 tumor cells with various amounts of PTHrP(1-34). Values are means \pm S.D. of 3-5 experiments in duplicate. Inset: Scatchard plot of ${ }^{125} \mathrm{I}-\mathrm{PTHrP}(1-34)$ binding data.

\section{Results}

\section{PTHrP binding}

Specific binding of ${ }^{125} \mathrm{I}-\mathrm{PTHrP}(1-34)$ ranged from $4 \%$ to $6 \%$ of total radioactivity added to W256 tumor cells. Meanwhile, nonspecific binding was between 2\% and 3\% in these cells. During binding incubation, ${ }^{125} \mathrm{I}-\mathrm{PTHrP}(1-$ 34 ) was not significantly degraded $(<5 \%)$, as assessed by trichloroacetic acid precipitation. PTHrP(1-34) dose dependently inhibited ${ }^{125} \mathrm{I}-\mathrm{PTHrP}(1-34)$ binding to W256 tumor cells (Fig. 1). Scatchard analysis of the saturation binding curves demonstrated the presence of a single class of high affinity binding sites with an apparent $K_{\mathrm{d}}$ of $17 \mathrm{nM}$, and a density of 90000 sites/cell (Fig. 1, inset). Addition of either EGF or Arg-vasopressin, at $1 \mu \mathrm{M}$, failed to displace ${ }^{125} \mathrm{I}-\mathrm{PTHrP}(1-34)$ bound (100\%) to W256 tumor cells, which was $92 \pm 10 \%$ and $102 \pm 5 \%$ respectively $(n=3)$.

\section{Immunocytochemistry}

Immunocytochemistry was also carried out to examine the presence of the PTHR in W256 tumor cells. Human OB cells, as positive control (Fig. 2B), and rat renal tissue (Largo et al. 1999), showed positive staining with an antibody recognizing the extracellular domain of this receptor. Using this antibody, distinct clusters of immunostaining were observed in W256 tumor cells (Fig. 2A). In contrast, these cells displayed no immunostaining upon incubation without the antibody (Fig. 2C). 

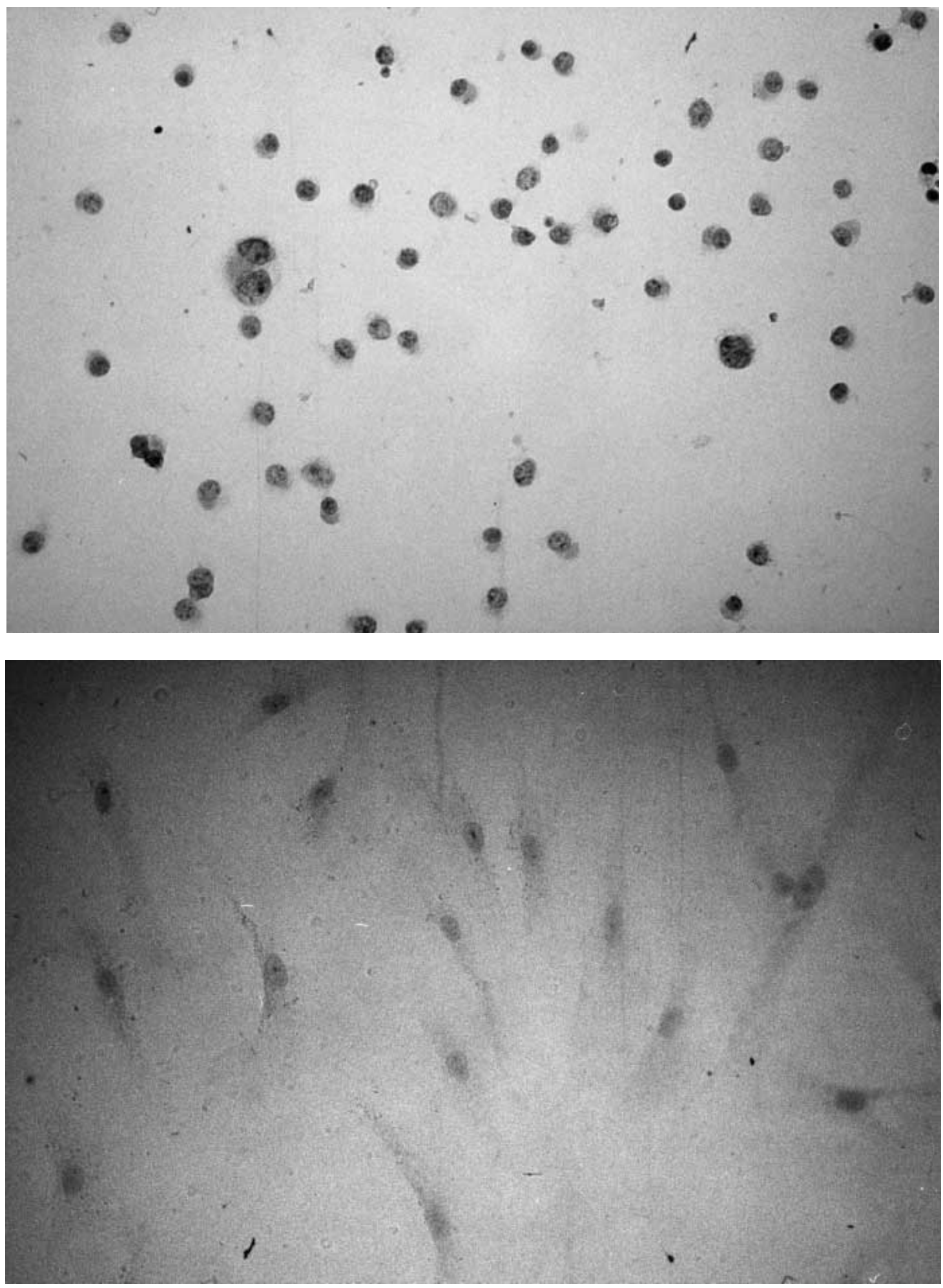

Figure $2(\mathrm{~A})$ and $(\mathrm{B})$. 


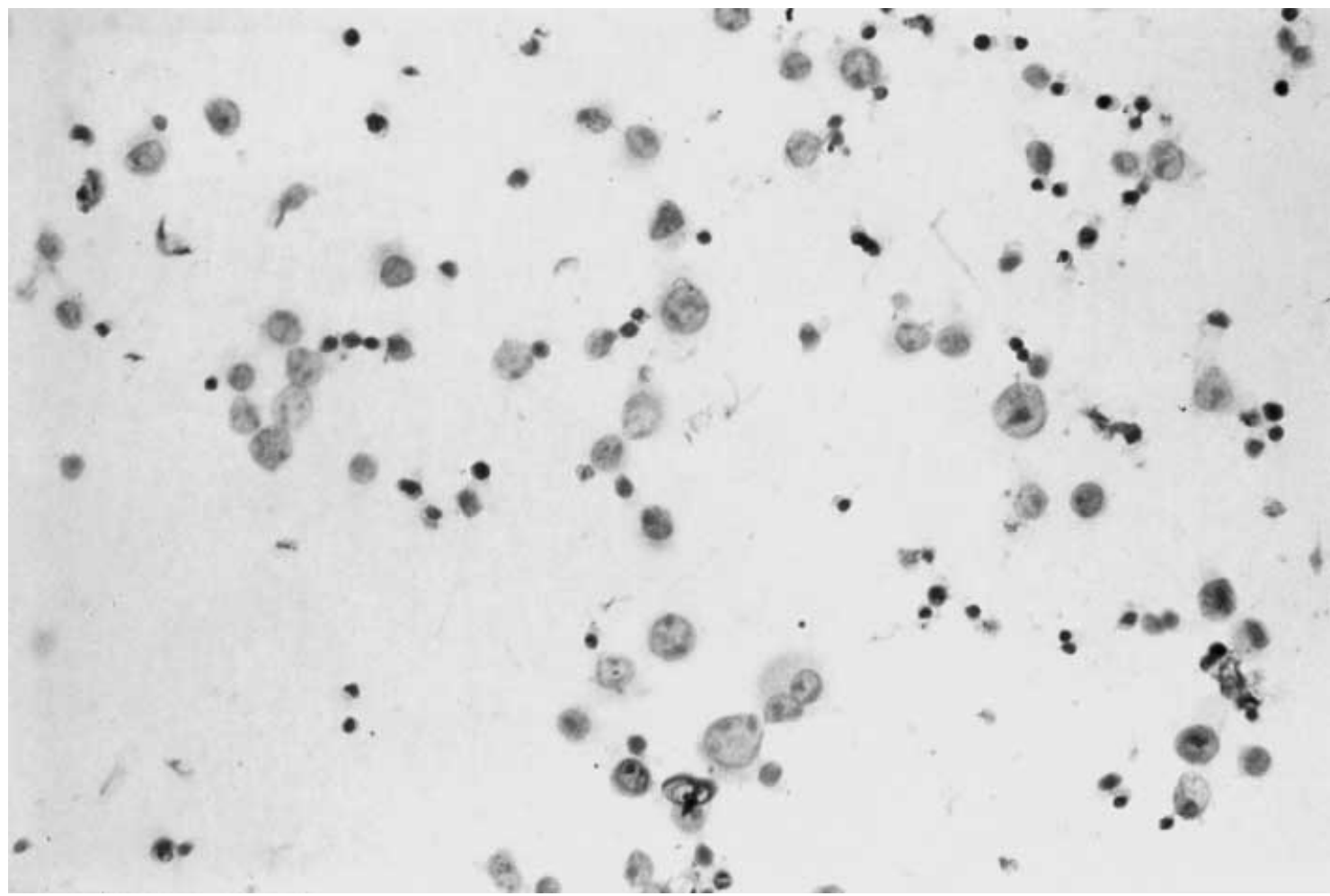

Figure $2(\mathrm{C})$.

Figure 2 Immunocytochemical staining for the PTHR in W256 tumor cells (A), and hOB cells (B). Negative control without primary antibody in W256 tumor cells is shown in (C). (Magnification, $\times 214(B) ; \times 340(A, C)$.)

\section{PTHR mRNA expression by RT-PCR}

Total and poly A A $^{+}$RA isolated from W256 tumor cells, and whole rat kidney total RNA as a positive control, were analyzed by RT-PCR, using primers amplifying two rat PTHR fragments. PCR analysis demonstrated the predicted products in either kidney or W256 tumor cells (Fig. 3). The nucleotide sequence of both PCR fragments obtained from W256 tumor cells RNA showed 100\% homology with those corresponding from kidney, and were identical to the rat cDNA gene sequence domain reported previously (Abou-Samra et al. 1992).

\section{cAMP-dependent PKA}

We previously found a lack of cAMP response to the $\mathrm{N}$-terminal region of $\mathrm{PTHrP}$, in contrast to the response triggered by forskolin, in W256 tumor cells (BenítezVerguizas \& Esbrit 1994). Since PKA activity appears to be a more sensitive indicator of PTHrP bioactivity than cAMP production (Martin et al. 1992), we assessed this activity in W256 tumor cells. We found that PKA activity in control cells was $0.41 \pm 0.08$; meanwhile, it was $0.42 \pm 0.05,0.60 \pm 0.09(P<0.01)$, or $0.76 \pm 0.13$
$(P<0 \cdot 01)$ after treating these cells with $1 \mu \mathrm{M}$ PTHrP $(1-$ 34), $1 \mu \mathrm{M}$ isoproterenol, or $10 \mu \mathrm{g} / \mathrm{ml}$ cholera toxin respectively $(n=5)$.

\section{Western blot analysis of $G_{a q / 11}$ protein}

Our previous results showed an intracellular calcium response, which is likely to occur by phospholipase C activation, to N-terminal PTHrP in W256 tumor cells (Benítez-Verguizas \& Esbrit 1994). In the present study, we specifically examined whether a $G_{\alpha q / 11}$ type of $G$ protein was present in these cells (Simon et al. 1991). Using a specific anti- $G_{\alpha q / 11}$ antibody, we detected a protein with an apparent molecular mass of $42 \mathrm{kDa}$ in W256 tumor cell membranes (Fig. 4), consistent with that of $G_{\alpha \mathrm{q} / 11}$ protein in other cells (Allgeier et al. 1994).

\section{GTPase assay}

Activation of $G$ protein-coupled receptors causes dissociation of the $G$ protein $\beta \gamma$ heterodimer from the $\alpha$ subunit-GTP complex displaying intrinsic GTPase activity (Simon et al. 1991, Thibonnier et al. 1993). 


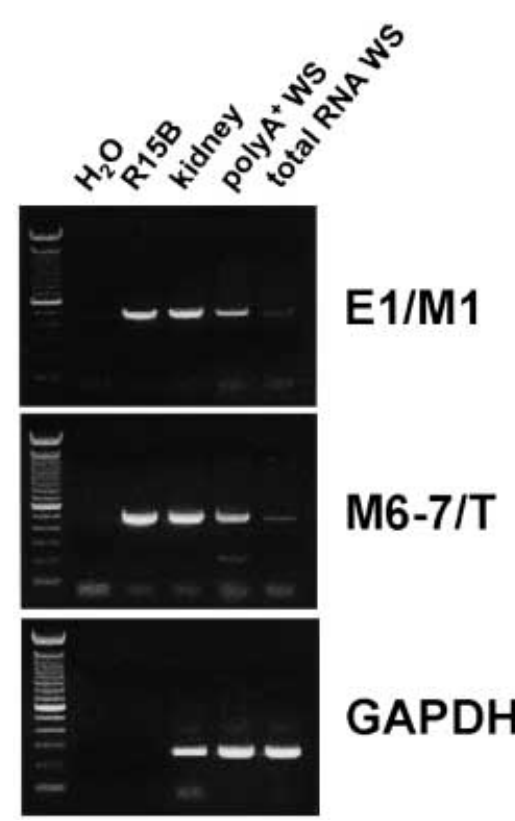

Figure 3 RT-PCR analysis of W256 tumor cell (WS) total or poly $\mathrm{A}^{+} \mathrm{RNA}$, and of rat kidney tissue total RNA, using specific primers yielding two fragments corresponding to the $\mathrm{N}$-terminal extracellular loop (exons E1/M1) or the C-terminal tail (exons M6-7/T) of the PTHR gene. The PCR product of a rat PTHR cDNA probe (R15B), negative control $\left(\mathrm{H}_{2} \mathrm{O}\right)$ without total RNA, and coamplified GAPDH product are also shown. PCR products were electrophoresed on $1.6 \%$ agarose gels. DNA markers are shown on the left.

Therefore, we used this approach to determine whether the $G_{\alpha q / 11}$ protein was coupled to the PTHrP receptor in W256 tumor cell membranes. Current evidence suggests that PTHrP(1-34) and PTHrP(1-36) were equivalent in binding to PTHR and the subsequent activation of phospholipase C (Abu-Samra et al. 1992, Jüppner et al. 1992, Schipani et al. 1993, Takasu \& Bringhurst 1998, Takasu et al. 1999). We found that PTHrP(1-36), between $1 \mathrm{nM}$ (Fig. 5) and $100 \mathrm{nM}$ (not shown), maximally increased GTPase activity in these cell membranes. This activity was dose-dependently inhibited by a specific anti- $\mathrm{G}_{\alpha \mathrm{q} / 11}$ antibody, but not by nonimmune $\operatorname{IgG}$ (Fig. 5).

\section{Discussion}

In the present study, analysis of the kinetics of PTHrP(134) binding to W256 tumor cells shows a single class of high affinity binding sites, with an apparent $K_{\mathrm{d}}$ of $17 \mathrm{nM}$, which is within the range of that found by some investigators (8-15 nM) for the PTHR (Abou-Samra et al. 1992, Schipani et al. 1993, Blind et al. 1995), although somewhat higher than that reported by others (within 0.3-6 nM) for this receptor (Jüppner et al. 1992, Iida-Klein et al. 1995, Takasu \& Bringhurst 1998, Takasu et al. 1999). This

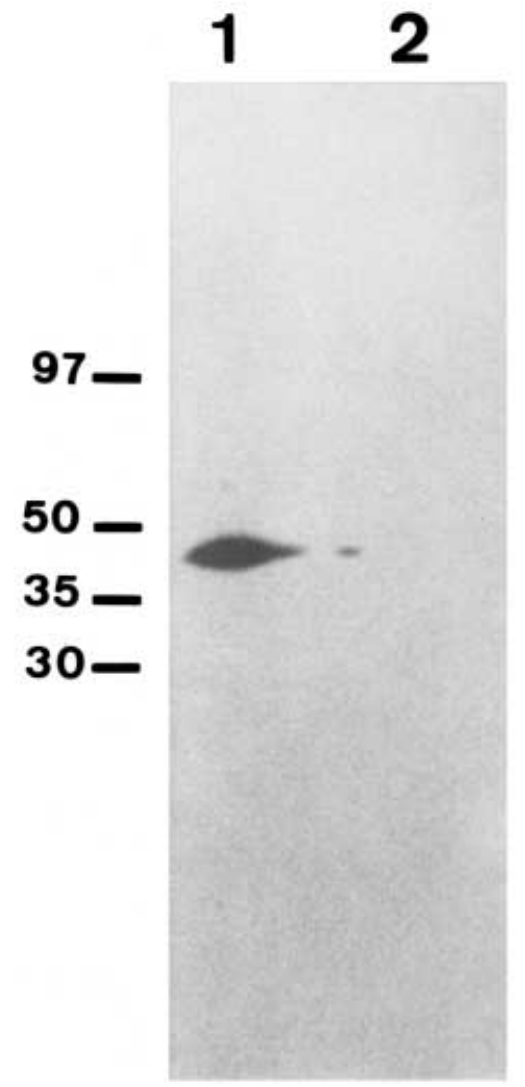

Figure 4 Western immunoblot analysis of W256 tumor cell membranes, using the anti- $\mathrm{G}_{\alpha \mathrm{q} / 11}$ antibody $(4 \mu \mathrm{g})$. The membrane was incubated with the antibody, preincubated with (lane 2) or without (lane 1) $4 \mu \mathrm{g} \mathrm{G}_{\mathrm{\alpha q} / 11}$. The molecular masses $\left(\times 10^{-3}\right)$ of protein markers are indicated.

moderately higher apparent $K_{\mathrm{d}}$ value compared with the latter range for PTHrP binding to W256 tumor cell membranes is unlikely to be accounted for by a high concentration of PTHrP receptors, but it might reflect an inefficient $G$ protein coupling (discussed below), as suggested occurs in some PTHR-transfected cells (Jüppner et al. 1992, Schipani et al. 1993, Blind et al. 1995, Iida-Klein et al. 1995, Takasu et al. 1999). In addition, we obtained a similar band by RT-PCR of either poly $\mathrm{A}^{+}$or total RNA from these cells and from rat kidney, using primers amplifying two fragments corresponding to either the extracellular domain or the C-terminal tail coding regions in the rat PTHR gene (exons E1-M1 and M6-7/T respectively). Thus, both the extreme $\mathrm{N}$-terminal region and the juxtamembrane end of the extracellular domain of the PTHR, necessary for promoting its surface expression and/or for ligand binding (Jobert et al. 1996, Carter et al. 1999), are likely to be homologous with the corresponding regions in the PTHrP receptor in W256 tumor cells. Moreover, these cells stain with an antibody recognizing an epitope in the extracellular domain of the rat PTHR, 


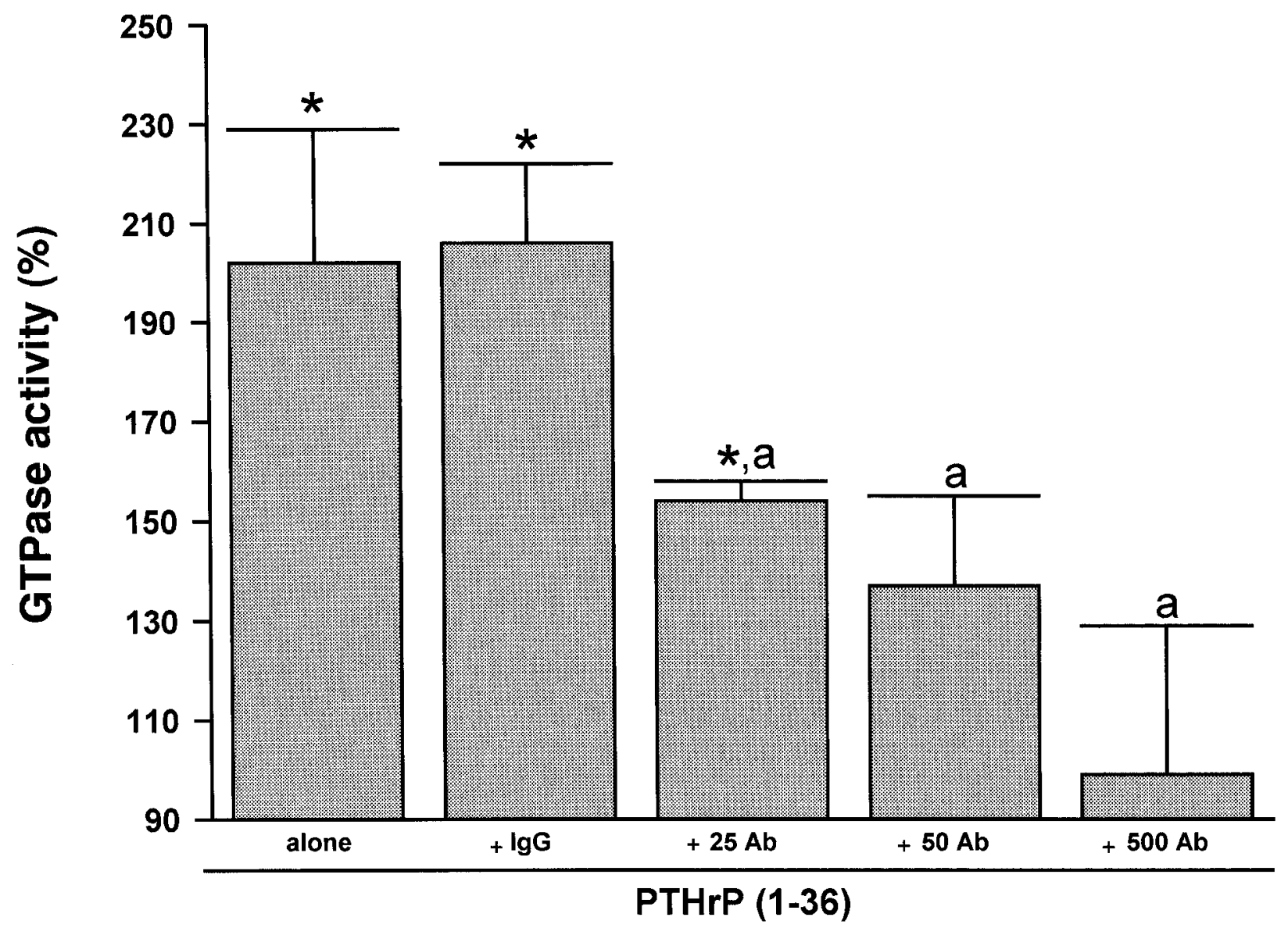

Figure 5 Effect of PTHrP(1-36) in the absence or presence of anti- $\mathrm{G}_{\alpha \mathrm{q} / 11}$ antibody $(\mathrm{Ab})$ at 25, 50, and $500 \mathrm{ng} / \mathrm{ml}$, or nonimmune IgG at $500 \mathrm{ng} / \mathrm{ml}$, on GTPase activity in W256 tumor cell membranes. PTHrP(1-36) was added at $1 \mathrm{nM}$. Values are means \pm S.D. of 3-5 experiments in duplicate. ${ }^{*} P<0 \cdot 01$ compared with nonstimulated control $\left(100 \pm 14 \%\right.$ or $\left.7 \pm 1 \mathrm{fmol} \times \mathrm{min}^{-1} \times \mathrm{mg}^{-1}\right)$; ${ }^{\mathrm{a}} P<0 \cdot 01 \mathrm{compared}$ with value corresponding to stimulation with $\operatorname{PTHrP}(1-36)$ alone.

encoded by exon E1 in this receptor gene-an exon apparently involved in its surface expression (Lee et al. 1994). Taken together, these findings suggest that both Nand C-terminal domains of the PTHrP receptor in W256 tumor cells are either identical to, or share high homology with, the corresponding domains in the PTHR. In this regard, the $2 \cdot 3-\mathrm{kb}$ transcript encoding the PTHR has recently been detected by Northern blot analysis in a W256 tumor strain different from that studied herein (Yaghoobian et al. 1998).

The PTHR cloned in bone and kidney cells activates both adenylate cyclase and phospholipase C pathways (Abou-Samra et al. 1992, Orloff et al. 1994, Takasu \& Bringhurst 1998, Takasu et al. 1999). However, in vascular smooth muscle cells, this receptor activates the cAMPdependent pathway but does not stimulate phospholipase $\mathrm{C}$, apparently due to a deficient PTHR coupling to the $\mathrm{G}_{\mathrm{q}}$ protein necessary for phospholipase $\mathrm{C}$ activation (Maeda et al. 1996). On the other hand, similar to findings in the
W256 tumor cells (Benítez-Verguizas \& Esbrit 1994, and present results), the $\mathrm{N}$-terminal region of $\mathrm{PTHrP}$ does not increase cAMP in HTLV-I-infected lymphocytes (McCauley et al. 1992), in squamous carcinoma cells (Orloff et al. 1992), and in both normal and transformed rat islet cells (Gaich et al. 1993, Villanueva-Peñacarrillo et al. 1999). However, in contrast with the present findings in W256 tumor cells, low affinity binding sites (apparent $K_{\mathrm{d}} 100 \mathrm{nM}$ ) have been found in both rat insulinoma cells and malignant keratinocytes (Orloff et al. 1992, Gaich et al. 1993). The latter cells express multiple mRNA transcripts of different size to the $2 \cdot 3-\mathrm{kb}$ transcript encoding the PTHR (Orloff et al. 1995). Moreover, both PTH and $\mathrm{PTHrP}$ activate adenylate cyclase in various squamous carcinoma cell lines after transfection with the PTHR, supporting the hypothesis that a receptor different from the PTHR, and not a defective $G_{\mathrm{s}}$ protein, mediates the altered cAMP response to $\mathrm{PTHrP}(1-34)$ in these cells (Orloff et al. 1995). On the other hand, but consistent 
with our findings in W256 tumor cells, HTLV-I-infected lymphocytes display high affinity binding sites for PTHrP(1-36), associated with increases in cytosolic calcium and unaltered cAMP (McCauley et al. 1992). To our knowledge, further characterization of this PTHrP receptor has not yet been carried out.

In the present report, in agreement with our previous findings (Benítez-Verguizas \& Esbrit 1994), we found that PTHrP(1-34) failed to induce a significant activation of PKA in W256 tumor cells. However, other $\mathrm{G}_{\mathrm{s}}$-dependent adenylate cyclase stimulatory agonists, such as cholera toxin and isoproterenol, produced a similar increase in PKA activity in these cells. On the other hand, we demonstrated the existence of a PTHrP receptor coupling to $G_{\alpha q / 11}$, which was detected in W256 membranes by Western blot analysis, in these cells. Previous studies with the full-length and truncated forms of the PTHR stably transfected in 293 cells showed that a region of the C-terminus beyond residue 483 of this receptor modulates $\mathrm{G}_{\mathrm{s}}$ activation (Schneider et al. 1994). Moreover, using COS-7 cells transiently expressing various PTHR constructs, the C-terminal region of this receptor has been shown to lower the apparent receptor affinity, and to decrease the efficacy of cAMP responsiveness without altering phospholipase $\mathrm{C}$ activation (Iida-Klein et al. 1995). However, the PCR product from RNA from W256 tumor cells, using primers amplifying a region encoding the whole C-terminal intracellular tail of the PTHR gene, was identical to the corresponding region in this gene. Thus, an alteration in this domain of the PTHrP receptor is unlikely to contribute to the lack of cAMP response to PTHrP in W256 tumor cells.

Malignant transformation of human keratinocytes with an activated $\mathrm{H}$-ras oncogene was shown to be associated with a reduced cAMP response to some agonists, including $\mathrm{PTHrP}(1-34)$ (Henderson et al. 1992). Moreover, PTHrP(1-34) stimulates cAMP but not intracellular calcium in human mammary cells, Hs578Bst, although Hs578T cells, originating from a mammary carcinoma in the vicinity of the normal breast tissue which was the source for the cell line Hs578Bst, do not respond to this peptide with increased cAMP production (Birch et al. 1995). However, in contrast to findings herein in W256 tumor cells, H-ras-transformed keratinocytes showed no binding to $\mathrm{PTHrP}(1-34)$ (Henderson et al. 1992), and Hs578T cells had no PTHR mRNA, using PCR with primers annealing to a domain encoding the N-terminal extracellular loop of this receptor (Seitz et al. 1993, Birch et al. 1995). Interestingly, a preliminary study in human mammary epithelial cell lines has shown that their increasing malignancy is associated with a switch from the cAMP pathway to the phospholipase C-intracellular calcium pathway after PTHR activation (Cataisson et al. 1998). Therefore, taken together, the aforementioned and present findings suggest that such a switch associated with PTHR activation might be a common event in malignant cells.
In summary, our data indicate that W256 tumor cells express the PTHR, which appears to be coupled to a $\mathrm{G}_{\alpha \mathrm{q} / 11}$ protein in these cells. Since several W256 tumor variants with different tumor features are available, this tumor could be a useful model to clarify the possible role of malignant transformation on the mechanism(s) involved in the PTHR uncoupling to adenylate cyclase.

\section{Acknowledgements}

This work was supported in part by a grant from the Spanish Ministry of Health (FIS 94/0269). We are indebted to Dr J J Orloff for providing us with the PTHR cDNA probe R15B. We are grateful to Dr M V AlvarezArroyo for helpful criticisms of the manuscript. J B-V and A V are fellows of the Conchita Rábago Foundation. F M is a postdoctoral researcher also supported by the Conchita Rábago Foundation.

\section{References}

Abou-Samra A-B, Jüppner H, Force T, Freeman MW, Kong X-F, Schipani E, Ureña P, Richards J, Bonventre JV, Potts JT Jr, Kronenberg HM \& Segre GV 1992 Expression cloning of a common receptor for parathyroid hormone and parathyroid hormone-related peptide for rat osteoblast-like cells: a single receptor stimulates intracellular accumulation of both cAMP and inositol trisphosphates and increases intracellular free calcium. PNAS 89 2732-2736.

Allgeier A, Offermanns S, van Sande J, Spicher K, Schultz G \& Dumont JE 1994 The human thyrotropin receptor activates G-proteins Gs and Gq/11. Journal of Biological Chemistry 269 13733-13735.

Benítez-Verguizas J \& Esbrit P 1994 Proliferative effect of parathyroid hormone-related protein on the hypercalcemic Walker 256 carcinoma cell line. Biochemical and Biophysical Research Communications 198 1281-1289.

Birch MA, Carron JA, Scott M, Fraser WD \& Gallagher JA 1995 Parathyroid hormone (PTH)/PTH-related protein (PTHrP) receptor expression and mitogenic responses in human breast cancer cell lines. British Journal of Cancer 72 90-95.

Blind E, Bambino T \& Nissensson RA 1995 Agonist-stimulated phosphorylation of the $G$ protein-coupled receptor for parathyroid hormone (PTH) and PTH-related protein. Endocrinology 136 4271-4277.

Carter PH, Shimizu M, Luck MD \& Gardella TJ 1999 The hydrophobic residues phenylalanine 184 and leucine 187 in the type-1 parathyroid hormone (PTH) receptor functionally interact with the amino-terminal portion of $\mathrm{PTH}(1-34)$. Journal of Biological Chemistry 274 31955-31960.

Cataisson C, Lieberher M, de Vernejoul MC, Calvo F \& Bouizar Z 1998 Expression of parathyroid hormone-related protein and $\mathrm{PTH} / \mathrm{PTHrP}$ receptor signaling during malignant transformation of human breast cell lines. Bone 23 (Suppl) S445 (Abstract).

Gaich G, Orloff JJ, Atillasoy EJ, Burtis WJ, Ganz MB \& Stewart AF 1993 Amino-terminal parathyroid hormone-related protein: specific binding and cytosolic calcium responses in rat insulinoma cells. Endocrinology 132 1402-1409.

García-Ocaña A, Gómez-Casero E, Peñaranda C, Sarasa JL \& Esbrit P 1998 Cyclosporine increases renal parathyroid hormone-related protein expression in vivo in the rat. Transplantation 65 860-863. 
Henderson JE, Kremer R, Rhim JS \& Goltzman D 1992 Identification and functional characterization of adenylate cyclase-linked receptors for parathyroid hormone-like peptides on immortalized keratinocytes. Endocrinology 130 449-457.

Hunter WM \& Greenwood FC 1962 Preparation of iodine-131labelled human growth hormone of high specific activity. Nature 194 495-496.

Iida-Klein A, Guo J, Xie LY, Jüppner H, Potts JT Jr, Kronenberg HM, Bringhurst FR, Abou-Samra AB \& Segre GV 1995 Truncation of the carboxyl-terminal region of the rat parathyroid hormone (PTH)/PTH-related peptide receptor enhances PTH stimulation of adenylyl cyclase but not phospholipase C. Journal of Biological Chemistry 270 8458-8465.

Jobert A-S, Fernandes I, Turner G, Coureau C, Prie D, Nissenson RA, Friedlander G \& Silve C 1996 Expression of alternatively spliced isoforms of the parathyroid hormone $(\mathrm{PTH}) / \mathrm{PTH}$-related peptide receptor messenger RNA in human kidney and bone cells. Molecular Endocrinology 10 1066-1076.

Jüppner H, Abou-Samra A-B, Freeman M, Kong XF, Schipani E, Richards J, Kolakowski LF Jr, Hock J, Potts JT Jr, Kronenberg HM \& Segre GV 1992 A G protein-linked receptor for parathyroid hormone and parathyroid hormone-related peptide. Science 254 1024-1026.

Laemmli UK 1970 Cleavage of structural proteins during the assembly of the head of bacteriophage T4. Nature 227 680-685.

Largo R, Gómez-Garre D, Santos S, Peñaranda C, Blanco J, Esbrit P \& Egido J 1999 Renal expression of parathyroid hormone-related protein (PTHrP) and PTH/PTHrP receptor in a rat model of tubulointerstitial damage. Kidney International 55 82-90.

Lee C, Gardella TJ, Abou-Samra A-B, Nussbaum SR, Segre GV, Potts JT Jr, Kronenberg HM \& Jüppner H 1994 Role of the extracellular regions of the parathyroid hormone $(\mathrm{PTH}) / \mathrm{PTH}-$ related peptide receptor in hormone binding. Endocrinology 135 1488-1495.

McCauley LK, Rosol TJ, Merryman JI \& Capen CC 1992 Parathyroid hormone-related protein binding to human T-cell lymphotropic virus type I-infected lymphocytes. Endocrinology 130 300-306.

Maeda S, Wu S, Jüppner H, Green J, Aragay AM, Fagin JA \& Clemens TL 1996 Cell-specific signal transduction of parathyroid hormone (PTH)-related protein through stably expressed recombinant $\mathrm{PTH} / \mathrm{PTHrP}$ receptors in vascular smooth muscle cells. Endocrinology 137 3154-3162.

Martin KJ, McConkey ChJ Jr \& Caulfield MP 1992 The role of protein kinase-A activity in the evaluation of agonist/antagonist properties of analogs of parathyroid hormone-related protein in opossum kidney cells. Endocrinology 131 2161-2164.

Martínez ME, García-Ocaña A, Sánchez M, Medina S, del Campo T, Valín A, Sánchez-Cabezudo MJ \& Esbrit P 1997 C-terminal parathyroid hormone-related protein inhibits proliferation and differentiation of human osteoblast-like cells. Journal of Bone and Mineral Research 12 778-785.

Orloff JJ, Wu TL, Heath HW, Brady TG, Brines ML \& Stewart AF 1989 Characterization of canine renal receptors for the parathyroid hormone-like protein associated with humoral hypercalcemia of malignancy. Journal of Biological Chemistry 264 6097-6103.

Orloff JJ, Ganz MB, Ribaudo AE, Burtis WJ, Reiss M, Milstone LM \& Stewart AF 1992 Analysis of parathyroid hormone-related protein binding and signal transduction mechanisms in benign and malignant squamous cells. American Journal of Physiology 262 E599-E607.
Orloff JJ, Reddy D, De Papp AE, Yang KH \& Soifer EN 1994 Parathyroid hormone-related protein as a prohormone: posttranslational processing and receptor interactions. Endocrine Reviews 15 40-60.

Orloff JJ, Kats Y, Ureña P, Schipani E, Vasavada RC, Philbrick WM, Behal A, Abou-Samra A-B, Segre GV \& Jüppner H 1995 Further evidence for a novel receptor for amino-terminal parathyroid hormone-related protein on keratinocytes and squamous carcinoma cell lines. Endocrinology 136 3016-3023.

Philbrick WM, Wysolmerski JJ, Galbraith S, Holt E, Orloff JJ, Yang KH, Vasavada RC, Weir EC, Broadus AE \& Stewart AF 1996 Defining the roles of parathyroid hormone-related protein in normal physiology. Physiological Reviews 76 127-173.

Schipani E, Karga H, Karaplis AC, Potts JT Jr, Kronenberg HM, Segre GV, Abou-Samra A-B \& Jüppner H 1993 Identical complementary deoxyribonucleic acids encode a human renal and bone parathyroid hormone (PTH)/PTH-related peptide receptor. Endocrinology 132 2157-2165.

Schneider H, Feyen JHM \& Seuwen K 1994 A C-terminally truncated human parathyroid hormone receptor is functional and activates multiple G proteins. FEBS Letters 351 281-285.

Seitz PK, Cooper KM, Ives KL, Ishizuka J, Townsend CM Jr, Rajaraman S \& Cooper CW 1993 Parathyroid hormone-related peptide production and action in a myoepithelial cell line derived from normal human breast. Endocrinology 133 1116-1124.

Simon MI, Strathmann MP \& Gautam N 1991 Diversity of G proteins in signal transduction. Science 252 802-808.

Simpkins H, Lehman JM, Mazurkiewicz JE \& Davis BH 1991 A morphological and phenotypic analysis of Walker 256 cells. Cancer Research 51 1334-1338.

Takasu H \& Bringhurst FR 1998 Type-1 parathyroid hormone (PTH)/ PTH-related peptide (PTHrP) receptors activate phospholipase $\mathrm{C}$ in response to carboxyl-truncated analogs of $\mathrm{PTH}(1-34)$. Endocrinology $1394293-4299$.

Takasu H, Guo J \& Bringhurst FR 1999 Dual signaling and ligand selectivity of the PTH/PTHrP receptor. Journal of Bone and Mineral Research 14 11-20.

Thibonnier M, Goraya T \& Berti-Mattera L 1993 G protein coupling of human platelet $\mathrm{V}_{1}$ vascular vasopressin receptors. American Journal of Physiology 264 C1336-C1344.

Valín A, García-Ocaña A, de Miguel F, Sarasa JL \& Esbrit P 1997 Antiproliferative effect of the C-terminal fragments of parathyroid hormone related protein, PTHrP-(107-111) and -(107-139), on osteoblastic osteosarcoma cells. Journal of Cellular Physiology 170 209-215.

Villanueva-Peñacarrillo ML, Cancelas J, de Miguel F, Redondo A, Valín A, Valverde I \& Esbrit P 1999 Parathyroid hormone-related peptide stimulates DNA synthesis and insulin secretion in pancreatic islets. Journal of Endocrinology 163 403-408.

Yaghoobian J, Morieux C, Denne MA, Bouizar Z, Ureña P \& de Vernejoul MC 1998 Pamidronate corrects the down-regulation of the renal parathyroid hormone (PTH)/PTH-related peptide (PTHrP) receptor mRNA in rats bearing Walker tumors. Hormone and Metabolic Research 30 249-255.

Received 26 November 1999

Accepted 21 March 2000 